\title{
Properties of Brass under Different Pouring Temperatures in Sand Casting Process
}

\author{
Poppy Puspitasari ${ }^{12^{*}}$, Avita Ayu Permanasari ${ }^{3}$, Andoko ${ }^{4}$, and Bayu Angga Pratama ${ }^{5}$ \\ ${ }^{1}$ Center of Nano Research and Advanced Materials, Universitas Negeri Malang \\ 2,3,4 Department of Mechanical Engineering, Faculty of Engineering, Universitas Negeri Malang \\ ${ }^{5}$ Bachelor Program, Mechanical Engineering Department, Universitas Negeri Malang \\ *poppy@um.ac.id
}

\begin{abstract}
This study aimed to determine the toughness of casts produced by the sand casting process at various temperatures against brass, and to investigate the structure contained in the cast madeusing abrass metal mould. This study was experimental research that observed the results of a treatment applied to a specimen group. This pre-experimental study usedthe one-shot case study model in which a group of samples was given treatment. The results showed that the specimen poured at $900^{\circ} \mathrm{C}$ exhibiteda microstructure consisting ofgood $\mathrm{Cu}-\mathrm{Zn}$ content, while that at $700^{\circ} \mathrm{Chad}$ the least $\mathrm{Cu}$ content. It indicates that the higher the temperature used for metal casting (brass), the more brittle the cast. The toughness of the materialwas influenced by the alloy composition and the pouring temperature of each specimen; the higher the pouring temperature, the better the treatment of alloy. The photomicrographs indicate that the higher the pouring temperature usedin the metal casting (brass), the lesser the carbon element contained in the material.
\end{abstract}

Copyright (C) 2017Journal of Mechanical Engineering Science and Technology

All rights reserved

Keywords: Brass casting, Toughness, Phase change

\section{Introduction}

Metals are elements found in mining ores and have the ability to conduct heat and electricity. At room temperature, all metals but mercury are in a solid state. Metals can melt when heated to a certain point (melting point) [1][2][3]. Metals can be obtained by mining into the ground at a certain depth. Generally, metals are in the form of rocks or sand called metal ores.

Brass is a metal that is widely used in households as well as in industry, but its use is mostly for household appliances and accessories [4]. This research was conducted to investigatethe characteristic of the alloy from wreck and brass residue fromcrucible furnace, whether or not it can be directly utilised for standard machining componentbased on its physical and mechanical properties [5]. The result of chemical testing shows that brass alloy contains the main elements of copper (CU) of $65.493 \%$ and zinc $(\mathrm{ZN})$ of $34.506 \%$ and other elements. Its tensile strength is $19.3055 \mathrm{~kg} / \mathrm{mm} 2$. The hardness is $\mathrm{HB} 110.44 \mathrm{~kg} / \mathrm{mm} 2$. This material isclassified as soft 4D brass $(\mathrm{CuZn})$ and thus brass castings are not yet feasible for use as thecore materials of machining components [6].

The variations inpouring temperature affect the solidificationof the brass casting;high pouring temperaturesincrease porosity. The toughness and hardness decrease due to alarge amount of hydrogen gas trapped in the brass cast. In the pouring process, it is necessary to adjust the pouring temperature. In fact, the pouring process has a significant influence on the casting quality; too low pouring temperatures cause short solidification, and poor fluidity causes casting failures. The higher the pouring temperature, the higher the gas solubility (especially hydrogen).

The impact test is a test performed atrapid loading tomeasure the resistance ofa material to shock loading [7][8]. In this test, a large amount of energy is absorbedwhen the load strikes the specimen. Microstructureis one of the elements determiningthe mechanical properties of a material.To identify the microstructure of a material,the phase diagram of the material has to be known [9]. The phase diagram is used for reference in the process of smelting, casting, crystallisation and others. 


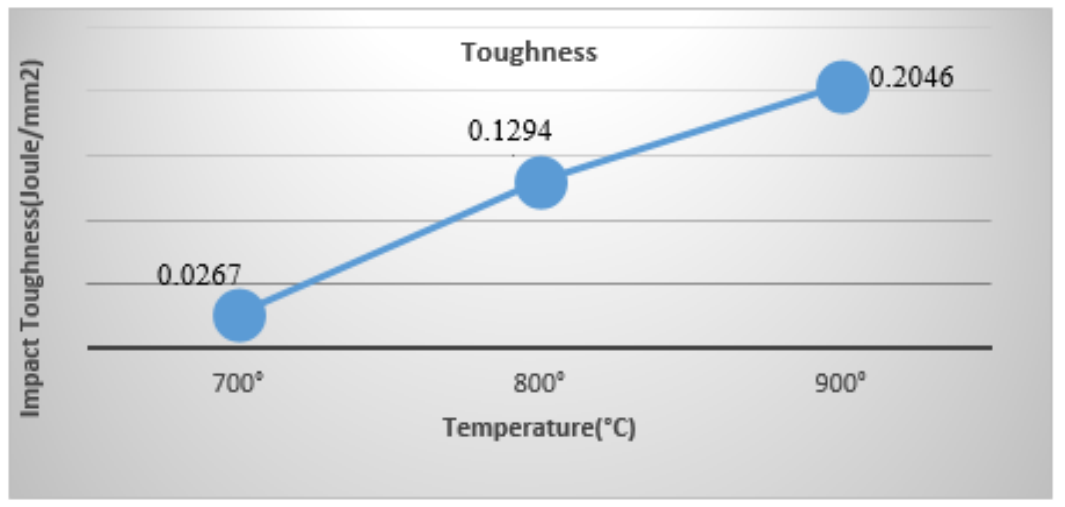

Fig. 1.Results of Impact Tests

\section{Research method.}

This research was pre-experimental with one-shot case study model, where a sample group was given a treatment and then observed [10]. The variables used in this research were 1) pouring temperature as the independent variable, 2) toughness and phase change as the dependent variables, and 3) brass (CuZn) and impact test as the control variables. The method used to analyse the data in this study was descriptive data analysis [11]. The descriptive analysis described the data on the impact test and phase change of brass (CuZn

\section{Results and discussion.}

\section{A. Impact Testing}

The result of descriptive analysis of impact testsis shown in figure 1.

1. The material poured at a temperature of $700^{\circ} \mathrm{C}$ had an average toughness of 0.0267 Joule/mm2,

2. The material poured at a temperature of $800^{\circ} \mathrm{C}$ had an average toughness of 0.1294 Joule/mm2,

3. The material poured at a temperature of $900^{\circ} \mathrm{C}$ had an average toughness of 0.2046 Joule/mm2.

The photomicrographsshowthe contents of cast results visible on the object surface after enlarged at a magnification of 600x. The opaque red areas are $\mathrm{Cu}$, the shiny white elements are $\mathrm{Zn}$, and the black spots are precipitate.

1. The specimen produced with a pouring temperature of $700^{\circ} \mathrm{C}$ consisted of $\mathrm{Cu}$ which was less visible compared to $\mathrm{Zn}$ which was larger. Also, the precipitate present in the specimen wasapparent.

2. The amount of $\mathrm{Cu}$ present in the specimen produced with a pouring temperature of $800^{\circ} \mathrm{C}$ was higherthan that of $700^{\circ} \mathrm{C}$; this is due to an increase in temperature variation. The photomicrograph shows that the size of copper increasedand the $\mathrm{Cu}$ atoms could enter the $\mathrm{Zn}$ crystal lattice well. Moreover, the amount of precipitate present on the specimen appeared to be less than the amount of carbon in the specimenproduced with a pouring temperature of $700^{\circ} \mathrm{C}$.

3. In the specimen produced with a temperature of $900^{\circ} \mathrm{C}$, the atoms of $\mathrm{Cu}-\mathrm{Zn}$ present could enter the crystal lattice ( $\mathrm{Zn})$ well. The higher the pouring temperature, the better the result. With the $\mathrm{Cu}$ atoms able to enter the $\mathrm{Zn}$ crystal lattice well, the precipitates were much more apparent. Also, twinning appeared at this temperature. Twinning occurs when a part of a crystallite changes its orientation so that the arrangement of atoms in that part becomes symmetrical with otherparts that do not experience twinning. The arrangement of atoms in this twinningpart is a mirror image of a part that does not have twinning. 


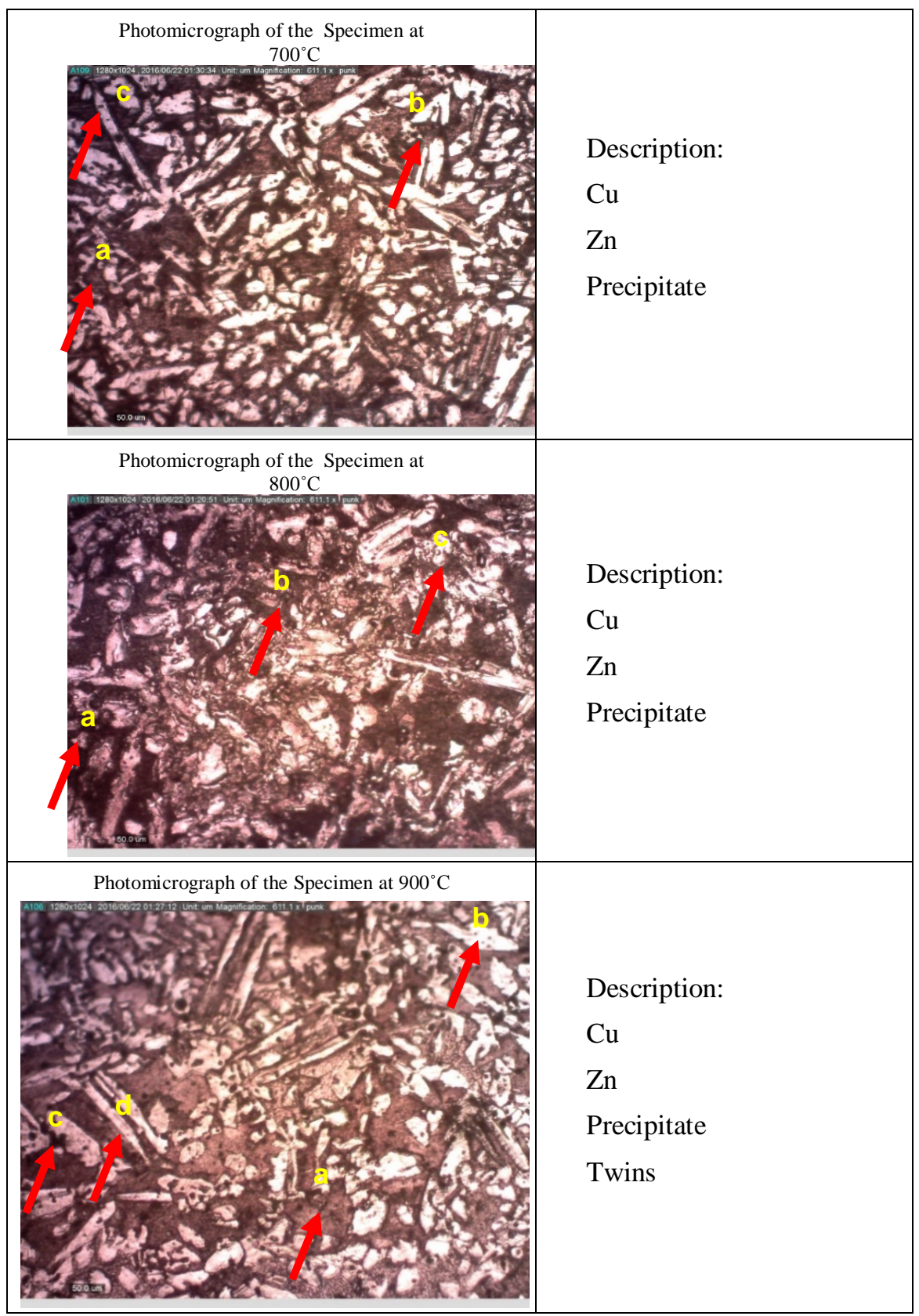

Fig. 2.Photomicrograph of $\mathrm{Cu}-\mathrm{Zn}$ (Brass)

Table 1. XRF (X-Ray Fluorescence) on $\mathrm{Cu}$-Zn composition at temperatures of $700^{\circ} \mathrm{C}, 800^{\circ} \mathrm{C}, 900^{\circ} \mathrm{C}$

\begin{tabular}{|c|c|c|c|}
\hline \multirow{2}{*}{ No } & \multirow{2}{*}{ Temperature } & \multicolumn{2}{|c|}{ Compound and Conc (\%) } \\
\hline & & Cu (aPhase) & Zn (vPhase) \\
\hline 1 & 7000 & $43.2+/-0.4$ & $27.1+/-0.7$ \\
\hline 2 & 8000 & $45.57+/-0.27$ & $29.4+/-0.3$ \\
\hline 3 & 9000 & $46.66+/-0.48$ & $30.2+/-0.4$ \\
\hline
\end{tabular}




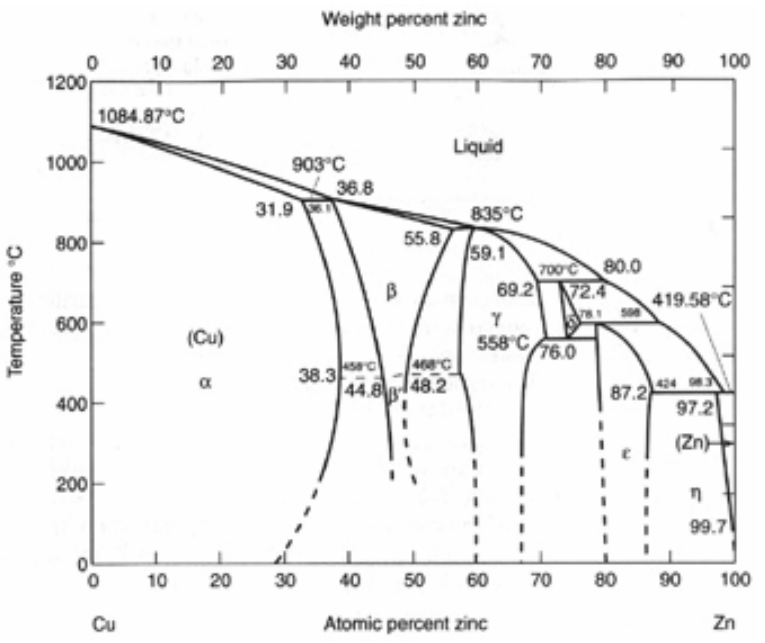

Fig. 3.Diagram ofphasebrass $(\mathrm{Cu}-\mathrm{Zn})$

\section{B. Phase Change of $\mathrm{Cu}$-Zn (Brass)}

The results of XRF (X-Ray Fluorescence) on $\mathrm{Cu}-\mathrm{Zn}$ composition at temperatures of $700^{\circ} \mathrm{C}$, $800^{\circ} \mathrm{C}, 900^{\circ} \mathrm{C}$ are as follows.

1. The alloy $(\mathrm{Cu}-\mathrm{Zn})$ poured at $700^{\circ} \mathrm{C}$ was at $\beta$ phasewhere a phase mixture was formed i.e. phase $(\alpha)$ with $(\mathrm{Cu})$ of $43.2+/-0.4$ and phase ${ }^{\curlyvee}$ with $(\mathrm{Zn})$ of $27.1+/-0.7$.

2. The alloy $(\mathrm{Cu}-\mathrm{Zn})$ poured at $800^{\circ} \mathrm{C}$ was at phaseyin which a mixtureof phase $(\alpha)$ with (Cu) of 45.57+/- 0.27 andphase ${ }^{\mathrm{y}}$ with $(\mathrm{Zn})$ of $29.4+/-0.3$ was formed.

3. The alloy $(\mathrm{Cu}-\mathrm{Zn})$ poured at $900^{\circ} \mathrm{C}$ was at phase $\gamma+\beta^{\prime}$ where a mixture of phase $(\alpha)$ with $(\mathrm{Cu})$ of $46.66+/-0.48$ and phase ${ }^{\mathrm{r}}$ with $(\mathrm{Zn})$ of $30.2+/-0.4$ was formed.

In each variation of temperature, there was precipitate. This precipitate was phase $\left({ }^{\prime}\right)$. Phase $\left({ }^{\prime}\right)$ was formed by the presence of other elements contained in brass $(\mathrm{Cu}-\mathrm{Zn})$. The temperatures of $700^{\circ} \mathrm{C}, 800^{\circ} \mathrm{C}, 900^{\circ} \mathrm{C}$ were in phase $\left(\beta^{\prime}+\gamma^{\prime}\right)$. Phase $\left(\beta^{\prime}\right)$ is the mixture of phase $(\alpha)$ i.e. $(\mathrm{Cu})$ and phase ( $\mathrm{v})$ i.e.(Zn); phase ( $\left({ }^{\prime}\right)$ is precipitate.

\section{Conclusion.}

1. Based on the research findings and discussion that have been elaborated, it can be concluded as follows:

2. The materialpoured at a temperature of $700^{\circ} \mathrm{C}$ had an average toughness of 0.0267 Joule/mm2,

3. The materialpoured at a temperature of $800^{\circ} \mathrm{C}$ had an average toughness of 0.1294 Joule/mm2,

4. The materialpoured at a temperature of $900^{\circ} \mathrm{C}$ had an average toughness of 0.2046 Joule/mm2.

5. The alloy $(\mathrm{Cu}-\mathrm{Zn})$ poured at $700^{\circ} \mathrm{C}$ was at $\beta^{\prime}$ phase where a mixture of phase $(\alpha)$ with $(\mathrm{Cu})$ of $43.2+/-0.4$ and phase $\mathrm{r}$ with $(\mathrm{Zn})$ of $27.1+/-0.7$ was formed.

6. The alloy $(\mathrm{Cu}-\mathrm{Zn})$ poured at $800^{\circ} \mathrm{C}$ was at phase $\gamma$ in which a mixture of phase $(\alpha)$ with $(\mathrm{Cu})$ of $45.57+/-0.27$ and phase ${ }^{\mathrm{r}}$ with $(\mathrm{Zn})$ of $29.4+/-0.3$ was formed.

7. The alloy $(\mathrm{Cu}-\mathrm{Zn})$ poured at $900^{\circ} \mathrm{C}$ was at phase $\gamma+\beta^{\prime}$ where a mixture of phase $(\alpha)$ with $(\mathrm{Cu})$ of $46.66+/-0.48$ and phase ${ }^{8}$ with $(\mathrm{Zn})$ of $30.2+/-0.4$ was formed. 


\section{References}

[1] T. Surdia and C. Kenji, metal casting techniques. Jakarta: PradnyaParamita, 1982.

[2] K. Sherope, Manufacturing Process for Engineering Materials Third Edition. USA: Addison-Wesley Publishing Company.Inc, 1995.

[3] T. Surdia, metal casting techniques. Jakarta: PradnyaParamita, 2000.

[4] T. Septiyantoro, "Planning for metal casting for packaging patterns," Universitas Atma Jaya, 2011.

[5] S. W. F, Structure and properties of enginering alloys, Second. 1993.

[6] S. M, "Firts-Principles study of phase stability in Cu-Zn subtitutional alloys," 1991.

[7] P. Murdanto, Material Teknik. Malang: Universitas Negeri Malang, 2017.

[8] G. Dwi Abdi, “Impact Testing,” 2014. [Online]. Available: http://sekarayuaulia.wordpress.com. [Accessed: 02-Apr-2015].

[9] Y. Ashari D, "Structure and material properties," Universitas Darma Persada, 2013.

[10] A. Suharsimi, Management Research. Jakarta: Rineka Cipta, 1990.

[11] Sugiyono, Quantitative Research Methods, Qualitative and R \& D. Bandung: Alfabeta Bandung, 2010. 